\title{
Lost Books and Dispersed Libraries in Sicily during the Seventeenth Century
}

\author{
Domenico Ciccarello
}

'Lost Books' in the Bibliographic Universe

The issue of lost books is truly an intriguing one. More often than not, we can feel that bibliographers leave us puzzled about their results when applying statistical methods in the computation of rates of loss. We recognize that this is especially true with investigations of the first centuries of print. Any attempts to speculate on rates of survival, aiming to provide reliable estimates of what has been lost, involve a large measure of conjecture. Too many independent factors are involved in instances of loss - sometimes, the loss of whole collections - over the centuries. Furthermore, many of those factors are likely to have had very variable effects in different parts of the European print domain. It may prove a hard task, by means of strict mathematical rules only, to account for the phenomena of long-term survival given how variable are the circumstances that cause books to be lost. As bibliographers we should be extremely careful as we could very easily get our calculations wrong. For all that, we believe that the effort is still worthwhile, if only because it makes perfect sense from an abstract, purely logical perspective.

We should always treat the 'bibliographic universe' as a mix of existing, lost and latent objects, irrespective of the bibliographic set under investigation. We refer to existing books whenever we are able to identify specific editions, ascertain their survival in one or more copies, and locate them either on library shelves, or in any other physical holding places. The notion of lost books, on the other hand, encompasses two rather different sets of records: all those identified editions/copies, whose former existence we are sure of, although they are known to us only through old bibliographies and catalogues and other suitable documentation, and editions or copies in a bibliographic set whose former existence we might reasonably try to estimate by statistical means, regardless of the possibility of identifying them. This latter bibliographic area (non-identified, i.e. supposedly once existing but now lost editions) may be addressed by modelling book loss rates with statistical curves, zero-graph estimations, and similar techniques. We should be aware, however, of the importance of the third level 
in the bibliographic universe (latent books), comprising all those editions that, despite their actual survival in at least in one copy, we still cannot identify or locate, often because they are waiting to be catalogued. We believe that, with respect to latent or 'hidden' books, the different national initiatives that have been put in place so far, encouraging libraries to engage in retrospective cataloguing, are likely to have a tremendous impact on scholarly estimates of survival and loss. In other words, we expect that, as long as cataloguing work gets institutional help to move forward, the bibliographic foundation of future estimations will become more complete and accurate. The stakeholders in each country should make it their concern to urge their institutions to reinforce cooperation projects, both at national and international levels, in the field of retrospective bibliography.

\section{Seventeenth-century Editions in Sicily and Their Bibliographic Treatment}

Coming now to the theme of cataloguing of seventeenth-century editions, we are confronted with a bibliographic context marked by broad international projects like the Heritage of the Printed Book in Europe database (Н Рв) or the Universal Short Title Catalogue (USTC), and country specific projects such as the German VD17. As for Italy, massive retrospective cataloguing seems to have been conducted only for the two first centuries of print. Since the development of Indice generale degli incunaboli (IGI) ${ }^{1}$ and of Edit16, the Central Institute for the Union Catalogue of Italian Libraries and Bibliographic Information (ICCU) has not launched any further nationwide projects. I am with those Italian scholars who might wish to campaign not only against the announced closure of Edit16, but also for the starting of an equivalent Edit17 programme.

In the absence of specific databases, the main sources for detecting seventeenth-century Italian editions can be listed as follows: a) the SBN opac for early printing; b) the MAI metaopac, capable of searching databases from some libraries and networks of libraries outside the SBN programme; c) OCLC database and other online catalogues worldwide, simultaneously accessible via the KVK metaopac (including the antiquarian booksellers' databases);

1 Centro nazionale d'informazioni bibliografiche (ed.), Indice generale degli incunaboli delle biblioteche d'Italia - IGI (Rome: Istituto poligrafico e Zecca dello Stato, Libreria dello Stato, 1943-1981), 6 vols. 
d) printed catalogues of single libraries or consortia of libraries, by language or by state of publication; e) special bibliographies; f) subject-based reference tools. ${ }^{2}$

\section{Found and Lost Books: Figures from a Bibliographic Census}

We now move to a specific case study, the reconstruction of the bibliographical output of seventeenth-century Sicily. Thus far, Sicily has not been particularly well served by the existing scholarly literature: only the city of Messina has been studied extensively, with a reasonably comprehensive survey of output, along with in-depth research conducted on printers and their mobility, false imprints, private libraries and the book trade. ${ }^{3}$ As for the other printing centres, relevant bibliographic information is available from just a few printed catalogues published on the initiative of libraries or single researchers in recent years. ${ }^{4}$ The absence of a comprehensive study of printing in Palermo

2 SBN online: <http://opac.sbn.it/opacsbn/opac/iccu/antico.jsp>; MAI online: <http://www .aib.it/aib/opac/mai2.htm3>; ocLC online:<http://www.ubka.uni-karlsruhe.de/kvk_en.html>, all accessed 30 September 2014. Amongst the printed catalogues, perhaps the best known is the Catalogue of seventeenth century Italian books in the British Library (London: The British Library, 1986); Roberto L. Bruni and D. Win Evans, Italian 17th-century books in Cambridge libraries. A short-title catalogue (Florence: Olschki, 1997); Roberto L. Bruni and D. Win Evans, Seicentine italiane nella National Library of Scotland (Florence: Olschki, 1998); Roberto L. Bruni and D. Win Evans, A catalogue of Italian books, 1601-1700 in Exeter libraries (Exeter: Exeter University Press, 1982); Suzanne and Paul-Henry Michel, Répertoire des ouvrages imprimés en langue italienne au XVII siècle conservés dans les bibliothèques de France (Paris: CNRS, 1967-1984). Amongst the special bibliographies, Sandro Piantanida, Lamberto Diotallevi and Giancarlo Livraghi, Autori italiani del '6oo. Catalogo bibliografico (Milan: Vinciana, 1948); to conclude with subject-based reference tools: Répertoire International des Sources Musicales (RISM) (Kassel: Bärenreiter, 1960-); Claudio Sartori, I libretti a stampa dalle origini al 1800 (Cuneo: Bertola \& Locatelli, 1993-1994), 7 vols.; Diritto e cultura nella Sicilia medievale e moderna. Le edizioni giuridiche siciliane, 1478-1699 (Soveria Mannelli: Rubbettino, 1994).

3 Maria Teresa Rodriquez (ed.), Catalogo delle edizioni messinesi dei secoli XV-XVIII (Palermo: Regione siciliana, Assessorato dei beni culturali e ambientali e della pubblica istruzione, 1997); Giuseppe Lipari, Gli annali dei tipografi messinesi del '6oo (Messina: Sicania, 1990); Cinque secoli di stampa a Messina (Messina: G.B.M., 1987); Giuseppe Lipari, Il falso editoriale a Messina (Messina: Centro interdipartimentale di studi umanistici - Università di Messina, 2001); Giuseppe Lipari, Una biblioteca messinese del '6oo (Messina: Sicania, 1990).

4 Edizioni catanesi dei secoli XVII-XVIII possedute dalla Biblioteca centrale della Regione siciliana (Palermo: Regione siciliana, Assessorato dei beni culturali e ambientali e della pubblica istruzione, 2003); Filippo Evola, Sulla stampa siciliana fuori di Palermo e di Messina nei secoli XVI e XVII. Ricordi bibliografico-letterari (Palermo: Tip. dello Statuto, 1885). For this subject, the best known study in Italy is the classic Francesco Barberi, Il libro italiano del 
during the seventeenth century is particularly deplorable, as Palermo played a very important political and socio-economic role during that period. ${ }^{5}$

A few years ago, I started work on a complete bibliography of seventeenthcentury editions printed in Sicily. ${ }^{6}$ The project, whose realization has been mainly based on systematic browsing of a wide range of information sources available both in printed form and online, is now complete. ${ }^{7}$ The bibliographic census consists of over 4,00o issues, including large formats as well as single-sheet ephemera, and also 'lost books'. ${ }^{8}$ In terms of editions, what is lost (i.e. issues listed in old bibliographies and catalogues, which cannot be matched to located copies), stands at about $19 \%$ of the corpus, at the time being. ${ }^{9}$ The following analysis of data extracted from the census may contribute to a trustworthy overview of the extent of survival of books printed

Seicento (Manziana: Vecchiarelli, 1990). As far as Sicily is concerned, some information on seventeenth-century printers and editions, along with historical notes, in Niccolò Domenico Evola, Ricerche storiche sulla tipografia siciliana (Florence: Olschki, 1940). A general overview of the subject is Carlo Pastena, 'Algunas reflexiones sobre la imprenta palermitana entre los siglos XVI y XVII', in Assunta Polizzi (ed.), Imprenta y cultura de interés hispánico en Sicilia en los siglos XVI and XVII (Bern: Peter Lang, 2013), pp. 23-36.

5 On the first three decades: Carlo Pastena, 'La tipografia palermitana al tempo del III duca d'Osuna (1600-1630)', in Encarnaciòn Sanchez Garcia and Caterina Ruta (eds.), Cultura della guerra e arti della pace. Il III Duca di Osuna in Sicilia e a Napoli, 1611-1620 (Naples: Pironti, 2012), pp. 339-352, although this small essay contains very few original observations and some bibliographic mistakes.

6 This became my doctoral research project at the University of Siena, with bibliographic and historical studies concentrated on the nine places where printing offices were active during the seventeenth century: Agrigento, Catania, Mazzarino, Messina, Militello, Monreale, Palermo, Polizzi and Trapani. I wish to express my deepest gratitude to my supervisor, Prof. Lorenzo Baldacchini.

7 Domenico Ciccarello, Le edizioni siciliane del XVII secolo, $\mathrm{PhD}$ thesis (Università degli Studi di Siena, 2012), currently under revision for publication.

8 When recording lost issues, a signum crucis $(\dagger)$ has been put before the identification number, the title has been given into square brackets, and the description has been limited to the elements provided by the source of information, which has then been referenced at the bottom of the entry. With regard to description criteria, for each record a wide range of elements has been given, including not only the author, title, place of publication, printer and date of publication, but also format and length, signature statement and fingerprint. The over 4,000 entries have been enhanced, whenever possible, with copy locations and links to full-text digital copies.

9 This number might have been different, if full bibliographic description coverage had already been achieved for seventeenth-century issues kept in our libraries. In other words, I believe that cataloguing of latent books could produce significant variations in these statistics on editions printed in Sicily. 
TABLE 10.1 Format of seventeenth-century Sicilian editions.

\begin{tabular}{lrr}
\hline Folio & 500 & $12.28 \%$ \\
Quarto & 1,781 & $43.73 \%$ \\
Octavo & 838 & $20.57 \%$ \\
Duodecimo & 670 & $16.45 \%$ \\
Other & 103 & $2.53 \%$ \\
Not available & 181 & $4.44 \%$ \\
Total & 4,073 & $100.00 \%$ \\
\hline
\end{tabular}

in Sicily between 1601 and 1700 . A statistical-mathematical approach, that could help to further address those unknown, hypothetically lost editions, is outside the scope of this paper, though it would certainly be reasonable to attempt such a thing.

We can observe in table 10.1 the 4,073 editions listed in the bibliography analysed by format of publication. The large predominance of the quarto is evident, followed by smaller formats (octavo, duodecimo), with a smaller but still significant number of folios. Other formats are present only in very small numbers. The smaller formats tend to survive in a markedly smaller number of copies, or are completely lost: this is true, for instance, of both the octavos and duodecimos in our list.

Table 10.2 shows the distribution of the editions by language, revealing that Italian books were much more common than Latin, with very few editions in other languages except Spanish or Sicilian (the one book in French is a truly exceptional case) $\cdot{ }^{10}$ Here again, the books in these minority linguistic categories characteristically survive in notably fewer copies than the Italian or Latin books.

If we turn to an analysis of our corpus, now classified according to the length of each text, this too offers some suggestive result (table 10.3). These calculations are based on the number of pages in each work (rather than sheets or gatherings). It clearly shows that shorter works of less than one hundred pages predominate. The high number of editions of unknown length is accounted for largely by lost books, detected through bibliographic tools which did not report

10 Robert Paris, Nuoua grammatica francese, et italiana nella quale sono contenute tutte le regole per imparare a ben leggere, pronunciare, intendere, parlare, e scriuere la lingua francese con molta facilità, e in breue. Con varii dialoghi francesi e italiani... In Messina, Bisagni, 1675. I have traced 6 copy locations of this edition (4 in Italy, 1 in France, 1 in Spain). 
TABLE 10.2 Language of seventeenth-century Sicilian editions.

\begin{tabular}{lrr}
\hline Latin & 1,252 & $30.74 \%$ \\
Italian & 2,562 & $62.90 \%$ \\
Spanish & 90 & $2.20 \%$ \\
Sicilian & 112 & $2.76 \%$ \\
French & 1 & $0.02 \%$ \\
Not available & 56 & $1.38 \%$ \\
Total & 4,073 & $100.00 \%$ \\
\hline
\end{tabular}

TABLE 10.3 Length (in pages) of seventeenth-century Sicilian editions.

\begin{tabular}{lrr}
\hline Over 30o pages & \multicolumn{1}{c}{677} & \multicolumn{1}{c}{$\mathbf{1 6 . 6 2 \%}$} \\
\hline $101-300$ & 743 & $18.24 \%$ \\
$51-100$ & 345 & $8.47 \%$ \\
$1-50$ & 1,408 & $34.57 \%$ \\
Not available & 900 & $22.10 \%$ \\
Total & 4,073 & $100.00 \%$ \\
\hline
\end{tabular}

any information on the book's size. Here, again, we will observe a clear relationship between a book's length and the prospects of survival.

Table 10.4 represents the distribution of editions by date, calculated in four periods of 25 years. Here the increase in output over the four periods seems to indicate not only the constant expansion of book production in Sicily (almost doubled from the first half to the second half of the century), but also the importance of the passage of time as a key factor in itself in determining the rate of loss. ${ }^{11}$

As for places of publication, shown in the first column of data in table 10.5, Palermo proves to be the largest centre of production with more than twice the number of Messina, the second major centre. In other smaller places we have

11 It is worth noticing that a bibliographic census of books printed in Palermo during the sixteenth century lists 431 editions, 147 of which (that is around $35 \%$ ) have no surviving copies. See Biblioteca centrale della Regione siciliana, Bibliografia delle edizioni palermitane antiche, vol. I, Edizioni del XVI secolo (Palermo, Assessorato regionale dei Beni culturali e ambientali e della pubblica istruzione, 1998). 
TABLE 10.4 Seventeenth-century book production in Sicily by date.

\begin{tabular}{lrr}
\hline $1676-1700$ & 1341 & $32.93 \%$ \\
$1651-1675$ & 1212 & $29 \cdot 76 \%$ \\
$1626-1650$ & 932 & $22.88 \%$ \\
$1601-1625$ & 576 & $14.14 \%$ \\
Not available & 12 & $0.29 \%$ \\
Total & 4,073 & $100.00 \%$ \\
\hline
\end{tabular}

TABLE 10.5 Sicilian printing places and loss rate.

\begin{tabular}{llll}
\hline Place & Editions & Lost editions & Surviving in place \\
\hline Agrigento & $4(0.09 \%)$ & $1(25.00 \%)$ & $0(0.00 \%)$ \\
Catania & $156(3.83 \%)$ & $43(27.56 \%)$ & $53(33.97 \%)$ \\
Mazzarino & $17(0.41 \%)$ & $2(11.76 \%)$ & $7(41.17 \%)$ \\
Messina & $1014(24.89 \%)$ & $204(20.11 \%)$ & $422(41.61 \%)$ \\
Militello & $8(0.19 \%)$ & $5(62.50 \%)$ & $3(37.50 \%)$ \\
Monreale & $7(0.17 \%)$ & $0(0.00 \%)$ & $6(85.71 \%)$ \\
Palermo & $2793(68.57 \%)$ & $504(18.04 \%)$ & $1882(67.38 \%)$ \\
Polizzi & $1(0.02 \%)$ & $0(0.00 \%)$ & $1(100 \%)$ \\
Trapani & $73(1.79 \%)$ & $22(30.13 \%)$ & $14(19.17 \%)$ \\
Total & 4073 & $781(19.17 \%)$ & $2388(58.63 \%)$ \\
& & & \\
\hline
\end{tabular}

a spectrum from 1 unique edition, in Polizzi Generosa, to 73 in Trapani and 156 in Catania. In each case I have calculated also the proportion of the known outpost currently believed to be lost (the middle column). The highest percentage of lost books is to be found in Militello in Val di Catania, whereas the smallest (leaving aside three places with very tiny outputs) is in Palermo, a loss rate of about $18 \%$.

The third column introduces a new angle of investigation. Here we record what we might call 'local survival', meaning editions where copies survive in the same area where they were originally printed. These last statistics have been obtained by matching the place of publication with the locations for each surviving copy. In this respect we can observe the best preservation rate in Polizzi, Palermo and Monreale, and the lowest percentages in Trapani and Catania. Historical circumstances may, of course, help account for these local 
differences. In the second half of the nineteenth century, public and university libraries in Palermo acted as a gathering place for vast collections from monastic libraries dispossessed as a consequence of confiscation laws. At the other extreme, we may reasonably suppose that the town of Catania (and other cities and villages surrounding Mount Etna) might have irretrievably lost a significant number of books due to a dramatic volcano eruption in 1669, followed by a tremendous earthquake in 1693. In these cases for many local editions, all surviving copies could have vanished as a result of this one traumatic event. ${ }^{12}$

\section{An Extraordinary Case of Dispersal: The Branciforti Library}

In the course of bibliographic work on Sicilian seventeenth-century printed books it is possible to come across outstanding examples of book loss. Militello in Val di Catania, a small feudal village positioned in the Sicilian hinterland, about 50 miles away from Mount Etna, provides us with a significant historical example of the dispersal of a huge book collection, that is the library established at the beginning of the seventeenth century by the Prince of Pietraperzia, Francesco Branciforti $\left(1545^{-1622}\right) .{ }^{13}$ The Prince of Pietraperzia was a distinguished member of the nobility and very close to the Spanish Court: he had married Juana de Austria (1573-1630), granddaughter

12 The above figures have been used only as a partial and limited study of how useful and reasonable it may be to explore the correlations between a bibliographic corpus of known (either surviving or lost) editions and the number of existing copies for each record. Further investigation would be needed to shed light on other equally crucial factors in loss rate, such as use, cost, literary genres, more or less ephemeral destination of works, local cultural tendencies, ease of transportation and circulation of items. Among the vast literature on the topic, focusing on the Italian scenario see at least Neil Harris, 'The Italian Renaissance book. Catalogues, censuses and survival', in Malcolm Walsby and Graeme Kemp (eds.), The book triumphant. Print in transition in the sixteenth and seventeenth centuries (Leiden: Brill, 2011), pp. $26-56$, and Neil Harris, 'La sopravvivenza del libro ossia appunti per una lista della lavandaia', Ecdotica, 4 (2007), pp. 24-65. For a very short theoretic essay, in which mathematical processes are applied to the estimation of loss rates in sixteenth-century Italian editions, see Alfredo Serrai, 'Stima del numero delle edizioni italiane del secolo XvI', Bibliotheca. Rivista di studi bibliografici, 1 (2002), pp. 53-56.

13 A biographical account of the Prince of Pietraperzia is given in Francesco Mallegni and Sebastiano Lisi (eds.), Archivistica e paleobiologia: due parametri per la ricostruzione del profilo storico e biologico del principe Francesco Branciforte di Militello in Val di Catania (Florence: Latini, 2003). 
to the Emperor Charles V. He was also extremely rich thanks to the revenues he could gather from his many land possessions. The Prince surrounded himself with a court of highly cultivated men like Pietro Carrera, Mario Gastone and Mario Tortelli. He also conceived an ambitious cultural programme based on two pillars: a private library ${ }^{14}$ and a private printing press. ${ }^{15}$ The latter marked the introduction of printing in Militello, with a production of at least nine editions; today, surviving copies are documented for only four of them. ${ }^{16}$

This required an enormous financial investment, above all for the systematic collecting of books. This resulted in the accumulation of a very considerable library, though it was destined only for a very short life, as the early death of Prince Branciforti in 1622 resulted in the sale of both the press (by his wife Juana to the bookseller Francesco Petronio) and the library (by his wife's daughter, Margaret to numerous purchasers).${ }^{17}$ The rapid dismantling of the Prince's cultural programme may explain why such a low percentage of the Militello editions have survived today, as they are now extremely rare. Il gioco degli scacchi (1617) is the first and the best known among the works printed in Militello, written by the priest and excellent chess player Pietro Carrera, and printed by Giovanni Rossi, native from Trento. The prefatory letter by Mario Tortelli reads as follows:

It is fair and convenient that the printing house is complemented with a library which for its richness and variety is renowned not only as the best

14 Salvina Bosco, 'Lo strano caso di una biblioteca', in Francesco Benigno (ed.), Tra memoria e storia. Ricerche su di una comunità siciliana: Militello in Val di Catania (Catania: Maimone, 1996), pp. 73-101.

15 A similar case of a private press started in Sicily by initiative of a rich nobleman occurred in Mazzarino towards the end of the same century, where Carlo Maria Carafa had a printing office in his palace for six years, from 1687 to 1692. See Domenico Ciccarello, 'Mobilità dei tipografi e committenza di aristocratici e religiosi nel XVII secolo', Paratesto, 10 (2013), pp. 121-148.

16 The four surviving editions are: Pietro Carrera, Il gioco degli scacchi (1617); Mario Tortelli, Dei madrigali...centuria prima (1620); Catanensis Ecclesiae Synodus dioecesana (1623) plus a single broadsheet, dated 1619 (only recently added to the 2012 census). As strange as it may seem, works by Francesco Branciforti himself are among the lost editions. On the products of the printing press in Militello, see Carmelo Erio Fiore, 'Sulla stampa a Militello in Val di Catania negli anni 1617-1623: le edizioni di Giovanni Rossi da Trento', Lèmbasi. Archivio storico, 1 (1995), pp. 29-50.

17 The contract was signed in 1622 by the notary Antonio Balba. The new printing house in Catania was jointly managed for some years by Francesco Petronio and Giovanni Rossi, then by Giovanni Rossi alone. 
in Sicily, but also among the most beautiful and rich in Italy, like this library owned by our Prince. ${ }^{18}$

The main source of information about the Branciforti library comes from a legal case of 1681-83 that pitted the monks of the Benedictine Abbey in Militello against the Prince's heirs, many years after his death. A good deal of documentation is kept in Palermo, including reports from several witnesses (people that had served the Prince's family in his palace when they were much younger) from which we can ascertain many detailed facts. ${ }^{19}$ We learn, for instance, about the construction of the library building by two notable architects, Mariano Interlizzi and Leonardo La Rocca; the names of the librarian, Francesco Petronio, and of the scholars who regularly used the library; ${ }^{20}$ the ways the books were acquired by the owner; and also the location of the printing press in which Giovanni Rossi worked to serve the Branciforti family and their intellectual circle. ${ }^{21}$

From the same documentation, we also learn more about how this extraordinary library of about 8,580 volumes came to be dispersed. The people of Militello were very conscious of the value of the treasure in their midst, to the extent that when Princess Margaret of Austria decided to sell the collection in Naples, they made appreciable attempts to save it; they had even made a proposal to gather money from the community, at their own expense, to persuade the owners to return the library to its original home. ${ }^{22}$

Nevertheless, the book collection would no longer be held in Militello. It was transferred to the Branciforti properties in Naples and then sold, partly in large lots and partly in smaller segments, in Naples and in Rome. A large proportion of the library seems to have passed to the Teatini monastery in Naples, until during the nineteenth century it was confiscated by the Italian State and given to the National Library in Naples. ${ }^{23}$ Other scholars believe that a portion of the books were purchased by the Oratorians in Naples, consequently becoming a

18 "Cosa molto di proporzione, e di convenienza, che accopiata fosse la stampa ad una Libreria tanto famosa, che in Cicilia di copiosità, di fioritezza, non che il primo luogo ritiene, ma gareggia colle più belle, e ricche d'Italia, com'è questa del Principe".

19 State Archives of Palermo. Fondo Lanza-Trabia (hereafter ASP.FT).

20 Mario Tortelli was Head of the Academy 'degli Impriggionati' and Nicolò Caruso 'degli Agghiacciati'. ASP.FT, 623, c. $303 v$.

21 ASP.FT, 459, C. 406r.

22 ASP.FT, 623, c. 33ov.

23 Antonio Blandini, 'La Biblioteca 'Palatina' di Militello in Val di Catania', Agorà, 10 (2002), pp. 34-36. 
TABLE 10.6 Distribution of the 8,580 books of the Branciforti collection.

\begin{tabular}{|c|c|}
\hline Libri spagnoli (8 casse, 618 libri) & Filosofia (9 casse, 653 libri) \\
\hline Libri di storia sacra ( 5 casse, 347 libri) & Casi di coscienza e di diritto canonico e \\
\hline Libri di poesie volgari (4 casse, 497 libri) & civile ( 13 casse, 697 libri) \\
\hline Libri di poesie latine ( 4 casse, 430 libri) & Libri spirituali ( 4 casse, 575 libri) \\
\hline Lettere umane ( 8 casse, 601 libri) & Controversie di teologia scolastica \\
\hline Miscellanee ( 5 casse, 385 libri) & (8 casse, 602 libri) \\
\hline Matematica (4 casse, 345 libri) & Sermonari (4 casse, 308 libri) \\
\hline Politica ( 4 casse, 467 libri) & Sacre scritture ( 20 casse, 763 libri) \\
\hline \multirow[t]{2}{*}{ Medicina ( 11 casse, 723 libri) } & Musica (32 libri) \\
\hline & Libri doppi (538 libri) \\
\hline
\end{tabular}

part of the Girolamini State Library; a collection that achieved a wholly unwelcome notoriety as a result of spectacular thefts in recent years. ${ }^{24}$

In the documentation of the 1681 trial, we also find some interesting indications on the content of the Branciforti library. The description of the collection is quite interesting in itself, although it is given in very general terms, by means of a list of the broad categories to which the books belong (see table 10.6), along with the number of boxes and volumes for each category. This gives us a clear idea of the pre-eminent cultural interests of Branciforti and his court, primarily medicine and religion, but also a wide range of literature, law and Hispanic books. These categories were also used to label the boxes when the books were shipped out of Militello.

The fact that Francesco Branciforti was able to accumulate such a collection in so short a time deserves some further comment. Paolo Baldanza, also called De Angelis, an eminent member of the Vatican Court, acted as a key intermediatory in ensuring that the almost embarrassing amount of money that Branciforti was eager to spend to build his collection mainly over the second decade of seventeenth century could be effectively disposed in the Rome book market. ${ }^{25}$ Vincenzo Branciforti, a clergyman and Francesco's uncle, contributed significantly to the overall growth of the library by selling his own,

24 Nicholas Schmidle, 'A Very Rare Book. The Mystery surrounding a copy of Galileo's pivotal treatise', The New Yorker, 16 December 2013, pp. 62-73.

25 The correspondence between Branciforti and Baldanza regarding the purchase of books from Rome is confirmed by witnesses at the trial, see ASP.FT 623, f. 308. The other books forming the Branciforti library were acquired partly at book fairs in Catania and Lentini, and partly from booksellers in Palermo, Catania, Messina and Militello. 
TABLE 10.7 Sample comparison between items listed in an inventory of the Branciforti library and a note of confiscated items belonging to the Girolamini State Library.

Militello list Naples list

Vita pontificum et cardinalium, in folio, un tomo

Nicolao Sandero, in ottavo, un tomo

Rocca, De sancta cruce, in ottavo, un tomo

Bellarminio, De officio principis, in ottavo, un tomo
Chacon, Alphonse. Vita et gesta summorum pontificum...necnon s.r.e. cardinalium Nicolai Sanderi De origine ac progressu schismatis Anglicani De particula ex pretioso et vivifico ligno Sacratissimae Crucis...A F. Angelo Rocca Bellarmino, Roberto. De officio principis christiani

well-furnished collection to his brother, who was happy to pass the books on to his son, Francesco. This latter circumstance offers us a unique perspective on the Branciforti books, thanks to an inventory which noted the titles of the books owned by Vincenzo, together with acquisition notes. ${ }^{26}$ From these notes we can infer that even from a small centre like Militello it was possible to take advantage of a wide range of book trade opportunities, such as local book fairs, travelling booksellers and other book networks across Italy and Europe. ${ }^{27}$

Unfortunately, the list of books in this document dated 1621 is fairly summary, so it provides little help in identifying the specific editions acquired by the Branciforti family. Even if we are mindful of the types of mistakes that could always occur when transcribing items in an inventory, which often lead to the creation of misleading bibliographic items, we should use further caution in dealing with this list, which is far from being detailed, as it reports only the author, title and only occasionally format, and then not for every item.

Nevertheless, if the absence of evidence is not evidence of absence, I am tempted to compare the list from Militello with another list, found in a truly casual way, browsing over the documentation produced by the judges who are

26 The inventory was authenticated through a notarial act redacted by notary Pietro Magro from Militello.

27 ASP.FT 623, various notes in ff. 567-597. 
dealing with the investigation on the recents thefts at the Girolamini Library. ${ }^{28}$ Setting some examples alongside one another (see table 10.7), it would seem that there is a good number of similarities between the two lists. We might even dare to hope that when the confiscated items return back to the Oratorians, from whom they have been stolen, and the Girolamini Library opens its doors to the public once again, then a visit might be worthwhile, to check whether any evidence of ownership, such as bookplates or manuscript notes, have been left to help us in discovering any item from the biggest private library in Sicily during the seventeenth century.

28 Part of the documentation relating to the ruling of the court for the Girolamini Library trial is available online: <http://www.penalecontemporaneo.it/materia/-/-/-/2430-la sentenza_di_primo_grado_per_la__spoliazione__della_biblioteca_dei_girolamini/> (accessed 30 September 2014). 